\title{
ANALISIS KESULITAN SISWA DALAM MENYELESAIKAN SOAL MATEMATIKA MATERI LUAS PERMUKAAN DAN VOLUME BANGUN RUANG SISI DATAR
}

\author{
Syifa Khoirunnisa1, Sulhan², Umi Kalsum³, Dorkas Lali Timbu', \\ Oktavianus Bulu Ngongo ${ }^{5}$, Mika Ambarawati ${ }^{6}$ \\ 1,2,3,4,5,6 Pendidikan Matematika IKIP Budi Utomo Malang
}

syifakhoirunnisa31@gmail.com ${ }^{1}$, sulhanphotografer@gmail.com² umik6134@gmail.com³ , dorkastimbu@gmail.com ${ }^{4}$, oktabungo28@gmail.com5, mikaambarawatio88@gmail.com ${ }^{6}$

\begin{abstract}
Abstrak
Sebagian besar siswa menganggap matematika sebagai mata pelajaran yang sulit dan membingungkan. Dari sekian banyak pokok bahasan, bangun ruang merupakan salah satu pokok bahasan matematika yang dianggap siswa paling sulit dipahami. Maka dari itu dilakukan penelitian mengenai kesulitan siswa dalam menyelesaikan materi bangun ruang. Tujuan penelitian ini adalah untuk mendeskripsikan kesulitan siswa dalam menyelesaikan soal matematika pada materi luas permukaan dan volume bangun ruang sisi datar khususnya balok. Penelitian ini merupakan penelitian kualitatif deskriptif. Berdasarkan penelitian yang telah dilakukan diketahui bahwa siswa kesulitan dalam memahami konsep dan definisi, kesulitan menerapkan rumus, dan kesulitan dalam perhitungan.
\end{abstract}

Kata kunci: kesulitan, menyelesaikan, bangun ruang

\begin{abstract}
Most students consider mathematics as a difficult and confusing subject of the many subjects, solid geometry is one of the mathematical subjects considered by students to be the most difficult to understand. Therefore a study was conducted on the difficulties of students in completing the material in solid geometry. The purpose of this study is to describe the difficulty of students in solving mathematical problems in the material surface area and volume of the solid geometry with flat side, especially rectangular solid. This research is a descriptive qualitative research. Based on research that has been done, it is known that students have difficulty understanding concepts and definitions, difficulty applying formulas, and difficulty in calculations.
\end{abstract}

Keywords: difficulty, solve, solid geometry

\section{PENDAHULUAN}

Bangun Ruang (dimensi 3) merupakan salah satu materi dalam matematika yang mulai diperkenalkan dalam jenjang pendidikan pada 
Syifa Khoirunnisa, Sulhan, Umi Kalsum, Dorkas Lali Timbu, Oktavianus Bulu Ngongo, Mika Ambarawati

Analisis Kesulitan Siswa dalam Menyelesaikan Soal Matematika Materi Luas Permukaan dan Volume Bangun Ruang Sisi Datar

Sekolah Dasar. Materi bangun ruang biasanya mulai diajarkan di kelas V, namun sudah mulai diperkenalkan juga di kelas II SD, walaupun hanya diajarkan tentang unsur-unsur bangun ruang saja. Standar kompetensi yang harus dikuasai oleh siswa dalam mempelajari bangun ruang, yaitu memahami macam-macam bangun ruang, memahami unsur-unsur bangun ruang, dan memahami konsep rumus-rumus luas permukaan serta volume bangun ruang. Tujuan pembelajaran bangun ruang di tingkat SMP dan sederajat bukan hanya tentang pemahaman konsep, namun juga aplikasi dalam kehidupan sehari-hari. Dengan demikian, pemahaman konsep bangun ruang akan berpengaruh pada pembelajaran bangun ruang selanjutnya. Pembelajaran bangun ruang diawali dengan mengenali tentang macammacam bangun ruang dan unsur-unsurnya, selanjutnya akan dijelaskan mengenai cara menentukan luas permukaan dan volume bangun ruang. Di samping itu siswa seharusnya sudah menguasai aljabar di kelas VII untuk menyelesaikan soal-soal tentang aplikasi bangun ruang dikehidupan seharihari.

Faktanya, tidak sedikit siswa yang menganggap matematika sebagai mata pelajaran yang sulit dan membingungkan. Dari sekian banyak pokok bahasan tersebut, bangun ruang merupakan salah satu pokok bahasan matematika yang dianggap siswa paling sulit dipahami (Agninditya, dkk. 2014: 795). Maka dari itu disini penulis memutuskan untuk menjadikan materi bangun ruang sebagai bahan penelitian, agar penulis dapat memberikan solusi dalam meningkatkan pemahaman siswa terhadap bangun ruang.

Hasil penelitian Chamundeswari (2014) menyatakan bahwa kesalahan konseptual membantu guru untuk memahami kesulitan siswa dan mengevaluasi tingkat pengetahuan siswa. Oleh karena itu, dalam penelitian ini penulis menggunakan instrumen soal cerita (masalah kontekstual) untuk meneliti sejauh mana siswa dapat menyelesaikan soal tersebut. Peningkatan mutu kegiatan belajar mengajar dapat dilakukan berdasarkan informasi kesalahan pada saat menyelesaikan soal-soal matematika. Banyak kesalahan yang dilakukan siswa dalam mengerjakan soal dapat menjadi petunjuk sejauh mana penguasaan siswa terhadap materi yang didapat (Hidayat, dkk. 2013: 40). Kesalahan yang dilakukan siswa dapat diteliti lebih lanjut mengenai penyebab kesalahan siswa. Penyebab kesalahan yang dilakukan siswa harus segera mendapat pemecahan yang tuntas. Pemecahan ini ditempuh dengan cara menganalisis akar permasalahan yang menjadi penyebab kesalahan yang dilakukan siswa.

Penelitian yang serupa dengan ini adalah penelitian Syahrir (2013) tentang kesulitan pemahaman konsep dan prinsip siswa pada materi dimensi 
Syifa Khoirunnisa, Sulhan, Umi Kalsum, Dorkas Lali Timbu, Oktavianus Bulu Ngongo, Mika Ambarawati

Analisis Kesulitan Siswa dalam Menyelesaikan Soal Matematika Materi Luas Permukaan dan Volume Bangun Ruang Sisi Datar

tiga, Yulfiana (2015) mengenai kesulitan siswa dalam menyelesaikan soal volume bangun ruang sisi lengkung, Endah (2016) mengenai analisis penyelesaian permasalahan luas permukaan serta volume prisma dan limas, Humaerah (2017) tentang analisis kesalahan siswa dalam menyelesaikan soal geometri, Mutia (2017) tentang kesulitan siswa dalam memahami konsep kubus balok dan alternatif pemecahannya, Nurjanatin, Sugondo \& Manurung (2017) mengenai kesalahan siswa dalam menyelesaikan soal cerita luas permukaan balok, Rizqiyyah (2018) tentang kesulitan siswa dalam menyelesaikan volum kubus dan balok, Mahmud (2019) tentang kesulitan siswa dalam menyelesaikan soal luas permukaan dan volume kubus.

Berdasarkan berbagai hal di atas maka perlu dicari kesulitan yang dialami siswa Kelas VIII E SMP Taman Siswa Malang dalam mempelajari bangun ruang, unsur-unsur bangun ruang, serta konsep luas permukaan dan volume bangun ruang. Disini diambil satu contoh bangun ruang saja yaitu balok sebagai bahan penelitian tentang pemahaman bangun ruang.

\section{METODE PENELITIAN}

Penelitian ini termasuk penelitian deskriptif kualitatif. Subjek penelitian ini adalah siswa kelas VIII E SMP Taman Siswa Malang sebanyak 22 siswa. Untuk mengambil keobjektifan penelitian diambil 3 siswa dari 22 siswa dalam kelas tersebut. Subjek penelitian terdiri dari 1 siswa nilai tertinggi sebagai subjek 1, 1 siswa nilai sedang sebagai subjek 2, dan 1 siswa nilai rendah sebagai subjek 3. Instrumen yang digunakan adalah lembar tes soal mengenai Balok dan lembar wawancara. Data yang dianalisis adalah adalah hasil dari tes dan wawancara. Teknik analisis data yang digunakan yaitu reduksi data, penyajian data, dan penarikan kesimpulan.

Soal tes yang diberikan kepada subjek terdiri dari dua soal. Soal yang pertama yaitu, sebuah bak penampungan air berbentuk balok di rumah Ani memiliki luas alas $7000 \mathrm{~cm}^{2}$, bak tersebut terisi air penuh dengan volume 560 liter. Pada suatu hari Ani memasukkan benda berbentuk balok dengan ukuran $25 \mathrm{~cm} \times 10 \mathrm{~cm} \times 50 \mathrm{~cm}$ ke dalam bak, sehingga menyebabkan air di dalam bak tumpah. Maka berapakah tinggi air dalam bak penampungan setelah Ani mengambil benda tersebut?. Soal yang kedua yaitu, sebuah bak penampungan air berbentuk balok di rumah Ani memiliki luas alas $24.100 \mathrm{~cm}^{2}$, bak tersebut terisi air penuh dengan volume 234 liter. Pada suatu hari Niko memasukkan benda berbentuk balok dengan ukuran $50 \mathrm{~cm} \times 30 \mathrm{~cm} \times 20 \mathrm{~cm}$ ke dalam bak, sehingga menyebabkan air di dalam bak tumpah. Maka berapakah tinggi air dalam bak penampungan setelah Ani mengambil benda tersebut? 
Syifa Khoirunnisa, Sulhan, Umi Kalsum, Dorkas Lali Timbu, Oktavianus Bulu Ngongo, Mika Ambarawati

Analisis Kesulitan Siswa dalam Menyelesaikan Soal Matematika Materi Luas Permukaan dan Volume Bangun Ruang Sisi Datar

\section{HASIL DAN PEMBAHASAN}

Berdasarkan hasil penelitian diperoleh hal-hal sebagai berikut.

\section{Analisis Kesulitan pada Memahami Konsep dan Definisi}

Berikut hasil tes subjek 1 yang memperoleh nilai tertinggi.

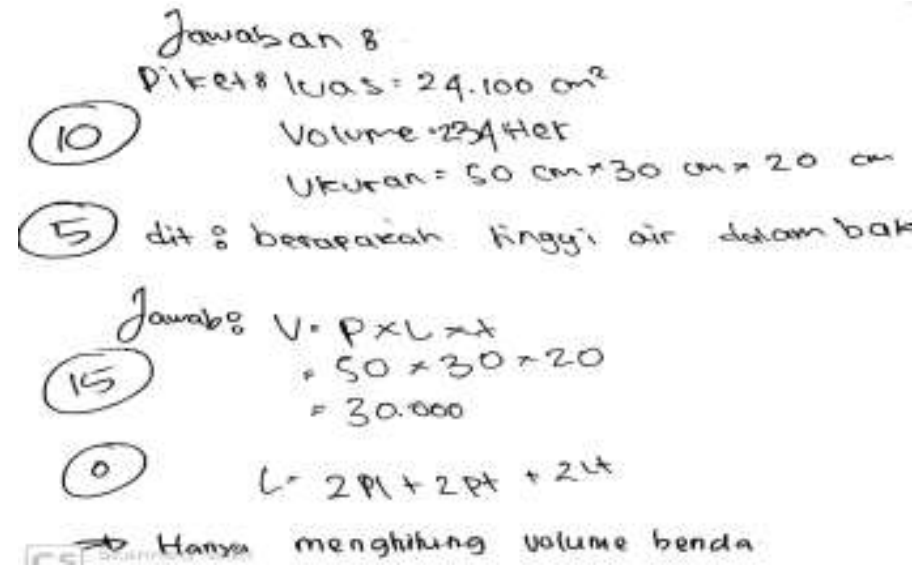

Gambar 1 Hasil Tes Soal Kedua dari Subjek 1

Berdasarkan hasil jawaban tertulis menunjukkan adanya kesulitan dalam memahami konsep dan definisi. Untuk lebih mengetahui kesulitannya maka dilakukan wawancara dengan subjek sebagai berikut, dengan P sebagai peneliti dan S1 sebagai subjek 1.

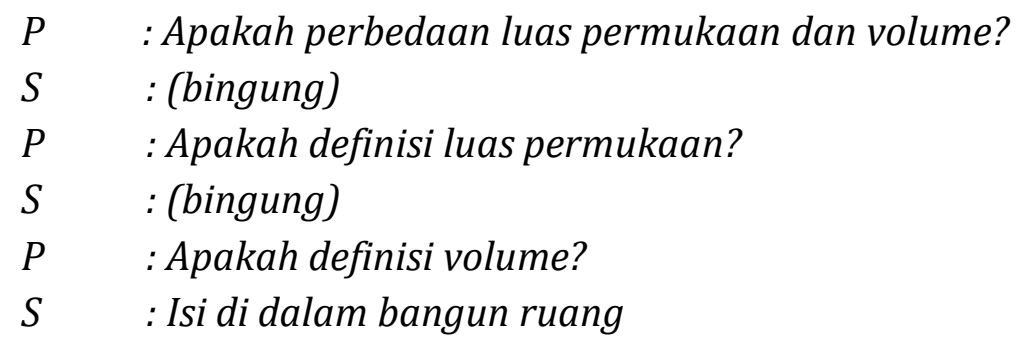

Berdasarkan petikan wawancara tersebut siswa belum benar-benar memahami definisi atau konsep dari luas permukaan dan volume bangun ruang. Namun, siswa telah memahami definisi dari volume bangun ruang sehingga siswa bisa mengerjakan soal tersebut, karena pada soal lebih difokuskan ke volume.

Berikut hasil tes subjek 2 yang memperoleh nilai sedang. 
Syifa Khoirunnisa, Sulhan, Umi Kalsum, Dorkas Lali Timbu, Oktavianus Bulu Ngongo, Mika Ambarawati

Analisis Kesulitan Siswa dalam Menyelesaikan Soal Matematika Materi Luas Permukaan dan Volume Bangun Ruang Sisi Datar

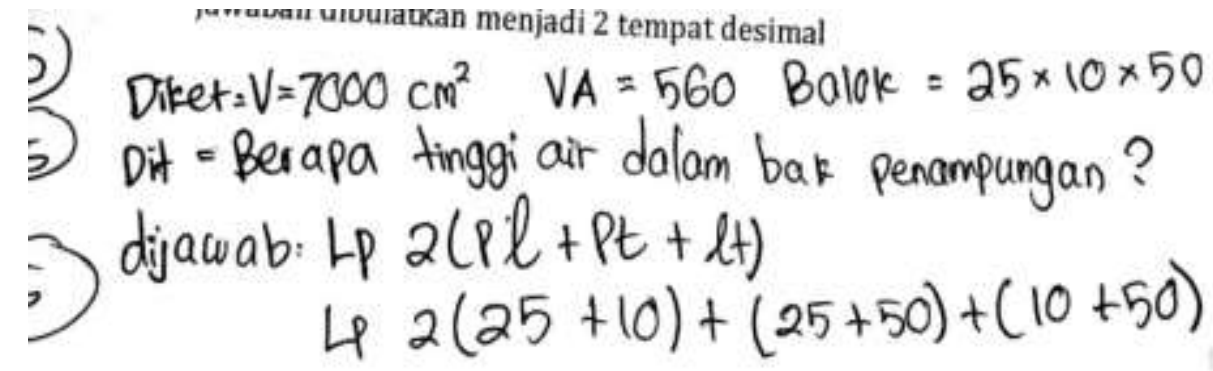

Gambar 2 Hasil Tes Soal Pertama dari Subjek 2

Wawancara juga dilakukan terhadap subjek 2 dengan petikan wawancara sebagai berikut, dengan P sebagai peneliti dan S2 sebagai subjek 2.

P $\quad$ : Rumus apa yang digunakan untuk menyelesaikan soal tersebut? Mengapa tidak menggunakan rumus luas permukaan?

S2 : Karena soal berfokus terhadap volume

$P \quad$ : Apakah perbedaan luas permukaan dan volume?

S2 : Tidak tahu

$P \quad$ : Jika terdapat balok tanpa tutup, apakah dalam menghitung luas permukaan tutupnya juga dihitung?

S2 : Tidak

Berdasarkan wawancara di atas siswa kurang memahami tentang luas permukaan dan volume bangun ruang, sehingga sulit untuk mengungkapkannya. Dalam soal yang dikerjakan ini yosua kesulitan dalam menghitung nya sehingga hanya mengerjakan sampai menemukan volume air setelah benda di ambil.

Berikut hasil tes subjek 3 yang memperoleh nilai terendah.

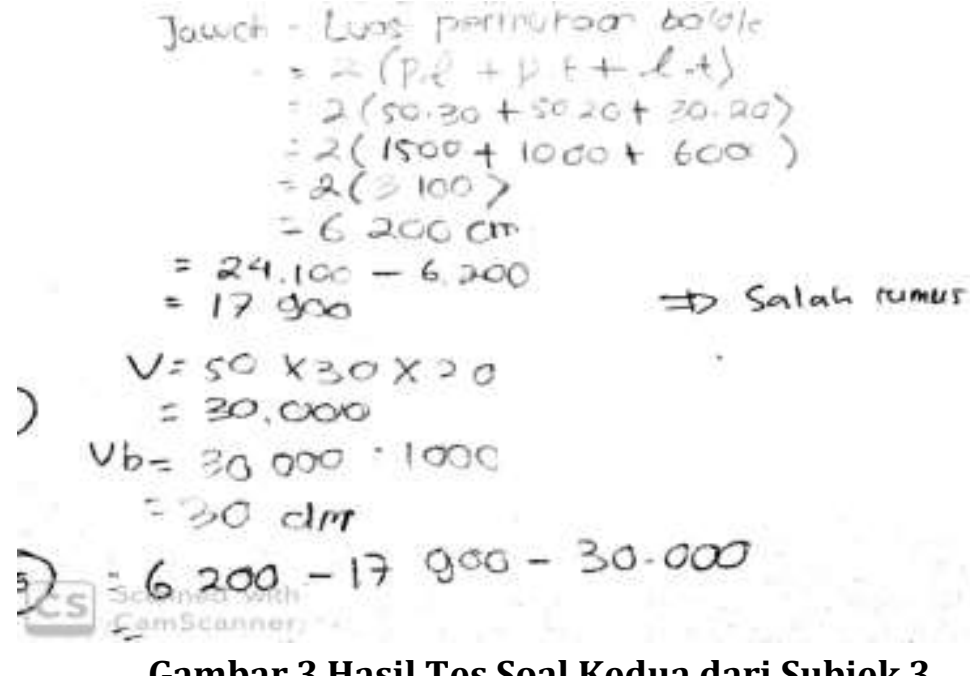


Syifa Khoirunnisa, Sulhan, Umi Kalsum, Dorkas Lali Timbu, Oktavianus Bulu Ngongo, Mika Ambarawati

Analisis Kesulitan Siswa dalam Menyelesaikan Soal Matematika Materi Luas Permukaan dan Volume Bangun Ruang Sisi Datar

Wawancara juga dilakukan terhadap subjek 3 dengan petikan wawancara sebagai berikut, dengan P sebagai peneliti dan S3 sebagai subjek 3.

P $\quad$ : Mengapa hanya sampai sini pengerjaannya?

S3 : Karena tidak tahu caranya

$P \quad$ : Apakah perbedaan luas permukaan dan volume?

S3 : Tidak tahu

Petikan wawancara dengan siswa tersebut menunjukkan belum memahami konsep dan definisi secara keseluruhan. Dengan demikian, siswa tidak bisa mengerjakan soal tersebut.

Berdasarkan petikan wawancara dengan ketiga siswa dapat disimpulkan bahwa siswa yang mendapat nilai tinggi dan sedang memahami konsep luas permukaan dan volume bangun ruang walaupun pemahaman itu masih kurang bagus, masih ragu-ragu dalam menjawab pertanyaan peneliti sedangkan siswa dengan nilai rendah belum memahami konsepnya secara keseluruhan.

Umumnya, siswa belum memahami konsep dari luas permukaan dan volume bangun ruang. Sebagian besar siswa hanya bisa menjawab yang diketahui dan ditanya saja tapi tidak bisa menentukan bagaimana penerapan aplikasi luas permukaan dan volume balok pada soal tersebut. Sehingga banyak yang bingung dalam menyelesaikan soal tersebut menggunakan rumus luas permukaan atau volume. Konsep luas permukaan dan volume bangun ruang baik sisi datar ataupun sisi lengkung merupakan suatu hal penting yang harus dikuasai oleh siswa. Konsep merupakan pengetahuan dasar matematika yang harus dikuasai oleh siswa, agar siswa dapat menyelesaikan persoalan matematika dengan baik dan benar. Begitu juga dengan definisi dari luas permukaan dan volume bangun ruang. Hal ini agar siswa dapat menyelesaikan permasalahan luas permukaan dan volume bangun ruang dengan tepat.

\section{Analisis Kesulitan dalam Menerapkan Rumus}

Analisis kesulitan dalam menerapkan juga didasarkan pada jawaban tertulis siswa. Siswa mengalami kesulitan dalam menerapkan rumus luas permukaan atau volume balok. Kesulitan terjadi apabila di dalam soal tidak secara langsung diperintahkan mencari luas permukaan atau volume. Hal ini menyebabkan cukup banyak siswa yang memberikan jawaban dengan tertukar-tukar rumusnya. Dalam tahap "dijawab" langkah pertama siswa harus menghitung volume benda yang dimasukkan ke dalam bak penampungan air menggunakan rumus volume. Namun cukup banyak yang justru mencari luas permukaan benda yang dimasukkan tersebut seperti di gambar 1 dan 2. Langkah kedua siswa harus mencari volume akhir setelah 
Syifa Khoirunnisa, Sulhan, Umi Kalsum, Dorkas Lali Timbu, Oktavianus Bulu Ngongo, Mika Ambarawati

Analisis Kesulitan Siswa dalam Menyelesaikan Soal Matematika Materi Luas Permukaan dan Volume Bangun Ruang Sisi Datar

benda diambil, namun banyak yang hanya menghitung volume benda saja seperti gambar 3. Jadi dapat disimpulkan bahwa banyak siswa yang kurang memahami konsep luas permukaan dan volume bangun ruang. Sebagian besar siswa mengalami kesalahan, bahkan tidak ada yang menjawab benar sampai akhir jawaban. Hal ini menunjukkan siswa belum menguasai konsep dari luas permukaan dan volume bangun ruang sehingga bingung apa yang ingin dicari pada soal tersebut dan asal-asal an dalam memakai rumus.

Berdasarkan hasil analisis jawaban tertulis menunjukkan adanya kesulitan dalam menerapkan rumus luas permukaan atau volume balok. Untuk lebih mengetahui kesulitan dalam memahami rumus luas permukaan atau volume balok maka dilakukan wawancara sebagai berikut. Petikan wawancara dengan subjek 1 sebagai berikut:

$P \quad$ : Bagaimana cara menyelesaikan soal ini ?

S1 : 547 dr 560-plt

$P \quad: 7000$ darimana?

S1 : Luas alas

$P \quad$ : Apa ada cara lain untuk mengerjakan soal ini ? Apa ada rumus lainnya?

S1 : Tidak

Dari petikan wawancara di atas menunjukkan siswa memahami jika rumus volume balok dapat digunakan untuk menyelesaikan soal tersebut. Siswa mampu mengerjakan dengan cara yang benar, namun mengalami kesalahan pada perhitungan akhirnya.

Petikan wawancara dengan subjek 2 sebagai berikut.

$P \quad$ : Rumus apa yang digunakan untuk menyelesaikan soal tersebut? Menapa tidak menggunakan rumus luas permukaan?

S2 : Karena dalam soal fokus terhadap volume

Dari petikan wawancara di atas menunjukkan siswa memahami jika rumus volume balok dapat digunakan untuk menyelesaikan soal tersebut. Siswa mampu mengerjakan dengan cara yang benar, namun siswa mengalami kebingungan dalam perhitungannya.

Petikan wawancara dengan subjek 3 sebagai berikut.

$P \quad$ : Untuk soal ini seharusnya menggunakan rumus apa?

S3 : Bingung

$P \quad$ : Apakah yang sebenarnya ditanyakan dalam soal?

S3 : :(membaca soalnya lagi)

Dari petikan wawancara di atas menunjukkan siswa tidak menyadari jika mengerjakan dengan rumus volume balok, padahal di jawaban tertulis penyelesaiannya dengan rumus luas permukaan balok. 
Syifa Khoirunnisa, Sulhan, Umi Kalsum, Dorkas Lali Timbu, Oktavianus Bulu Ngongo, Mika Ambarawati

Analisis Kesulitan Siswa dalam Menyelesaikan Soal Matematika Materi Luas Permukaan dan Volume Bangun Ruang Sisi Datar

Berdasarkan petikan wawancara dengan ketiga subjek diketahui bahwa subjek 1 dan 2 mengetahui bahwa yang diterapkan di soal adalah mengenai volume balok, namun subjek 3 mengalami kesalahan karena dia menggunakan rumus luas permukaan balok.

\section{Analisis Kesulitan dalam Perhitungan}

Subjek 2 dan 3 tidak dapat menyelesaikan masalah sampai pada tahap perhitungan. Berikut jawaban tertulis dari ketiga subjek terkait perhitungan yang dilakukan.

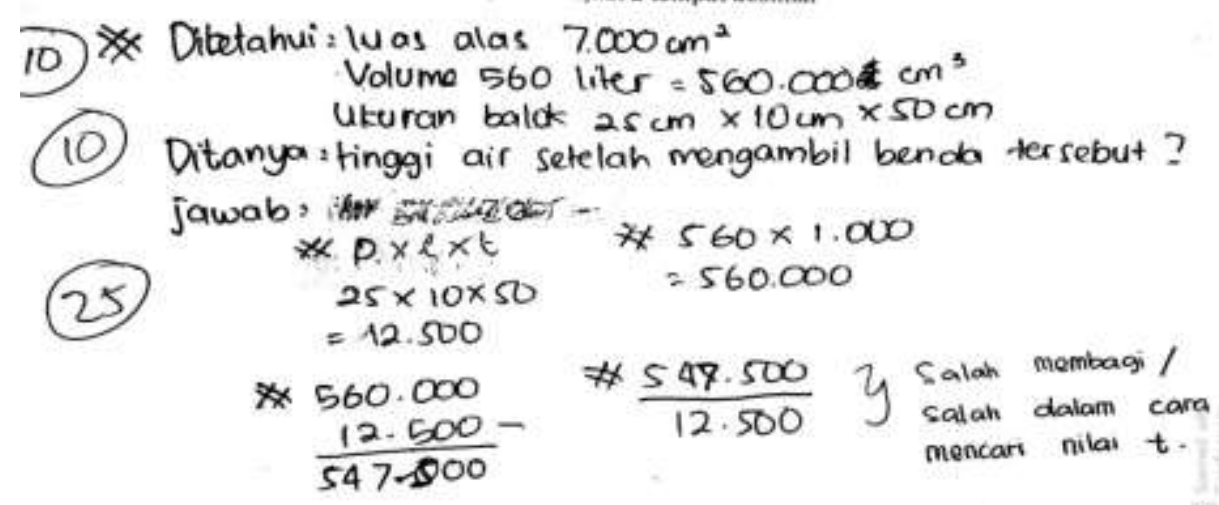

\section{Gambar 4 Hasil Kerja Soal Pertama Subjek 1}

Siswa masih banyak yang bingung dalam menentukan tinggi dari rumus volume. Untuk mencari tinggi setelah benda di ambil adalah $V=p \times l \times t \rightarrow$ $\frac{V}{p \times L}=t$. Siswa hanya asal membagi seperti yang ditunjukkan pada gambar 4 . Tetapi yang paling banyak adalah siswa berhenti mengerjakan hanya menghitung volume benda dan volume setelah benda diambil. Hal ini menunjukkan bahwa siswa masih mengalami kesulitan dalam penguasaan aljabarnya. Siswa masih bingung jika harus membolak-balik rumus atau memindah ruas variabel. Siswa seharusnya memahami tentang aljabar dan pembagian atau porogapit karena materi-materi tersebut sudah diberikan di jenjang sebelumnya. Karena penerapan materi tersebut selalu ada pada soalsoal kontekstual atau tekstual matematika.

Berdasarkan hasil analisis jawaban tertulis menunjukkan adanya kesulitan dalam perhitungan. Untuk lebih mengetahui kesulitannya maka dilakukan wawancara sebagai berikut. Petikan wawancara dengan subjek 1 sebagai berikut.

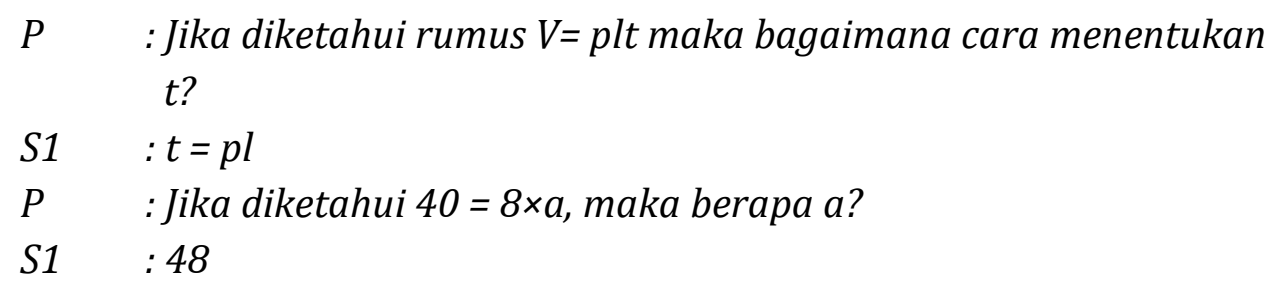


Syifa Khoirunnisa, Sulhan, Umi Kalsum, Dorkas Lali Timbu, Oktavianus Bulu Ngongo, Mika Ambarawati

Analisis Kesulitan Siswa dalam Menyelesaikan Soal Matematika Materi Luas Permukaan dan Volume Bangun Ruang Sisi Datar

Berdasarkan petikan wawancara subjek tersebut menunjukkan subjek masih kesulitan dalam mencari nilai $t$ atau kurang memahami aljabar. Hal ini yang menyebabkan subjek kesulitan bagaimana mencari $t$ walaupun di dalam jawaban tertulis sudah benar cara mencari $t$ nya.

Berdasarkan hasil analisis maka ditemukan kesulitan-kesulitan siswa yaitu sebagai berikut. Kesulitan dalam memahami konsep dan definisi adalah sebagai berikut. (1) Siswa mengalami kesulitan dalam memahami konsep luas permukaan dan volume bangun ruang sehingga siswa tidak dapat menjelaskan definisi secara lisan hal tersebut. Berdasarkan wawancara menunjukkan bahwa siswa yang memiliki nilai tinggi, sedang, dan rendah memiliki pemahaman konsep yang berbeda. (2) Siswa yang memiliki nilai rendah belum memahami konsep dan definisi luas permukaan dan volume bangun ruang secara menyeluruh. Untuk menjawab secara benar maka peneliti harus memberikan definisi dan memberikan contoh dahulu. Untuk kesulitan dalam menerapkan rumus yaitu Adanya siswa yang masih mengalami kesulitan dalam menerapkan rumus luas permukaan atau volume bangun ruang ini karena siswa belum memahami konsep luas permukaan dan volume bangun ruang secara menyeluruh.

Sedangkan kesulitan dalam perhitungan adalah sebagai berikut. (1) Pada umumnya siswa menjawab hanya sampai setengahnya yaitu mencari volume akhir setelah benda di ambil atau hanya menentukan volume benda saja. Jadi kesulitan perhitungan ini hanya dialami oleh sedikit siswa. Sebagian besar siswa masih kurang dalam penguasaan aljabarnya sehingga mereka sulit menentukan nilai $t$ dari rumus volume. Namun, setelah diberikan penjelasan ulang dan contoh maka siswa dapat menjawab dengan benar. Dengan demikian, siswa perlu mempelajari kembali tentang aljabar. (2) Siswa juga kesulitan dalam pembagian bilangan yang besar. Karena dari siswa yang dapat menjawab sampai akhir hanya sedikit dan tidak bisa menemukan nilai akhir atau mengalami kesalahan dalam menghitung nilai akhir. Hal ini menunjukkan bahwa siswa masih kesulitan dalam pembagian bilangan yang besar.

Berikut alternatif pemecahan yang dapat dilakukan untuk mengatasi kesulitan-kesulitan tersebut. Alternatif pemecahan untuk mengatasi kesulitan memahami konsep dan definisi adalah mengajarkan konsep luas permukaan dan volume bangun ruang dengan sederhana dan jelas. Hal ini dilakukan agar siswa tidak mengalami kesulitan dalam memahami dan tidak hanya menghafalkan banyak rumus. Selain itu, dapat menggunakan pembelajaran yang konstektual yaitu dengan menerapkan pada kehidupan sehari-hari atau menggunakan alat peraga dalam pembelajaran. Pembelajaran ini mempunyai komponen kontruktivisme, menemukan, 
Syifa Khoirunnisa, Sulhan, Umi Kalsum, Dorkas Lali Timbu, Oktavianus Bulu Ngongo, Mika Ambarawati

Analisis Kesulitan Siswa dalam Menyelesaikan Soal Matematika Materi Luas Permukaan dan Volume Bangun Ruang Sisi Datar

bertanya, adanya kelompok belajar, permodelan, dan penilaian autentik. Dengan demikian, siswa dapat memahami konsep dan definisi secara mudah.

Alternatif pemecahan untuk mengatasi kesulitan menerapkan rumus luas permukaan dan volume bangun ruang yaitu siswa diberikan banyak latihan soal tentang aplikasi luas permukaan dan volume bangun ruang. Dengan demikian, siswa dapat mengatasi kesulitan dalam memahami konsep dan definisi bangun ruang sehingga bisa menentukan kapan menggunakan rumus luas permukaan dan kapan menggunakan rumus volume.

Alternatif pemecahan untuk mengatasi kesulitan dalam perhitungan adalah lebih banyak belajar lagi soal-soal kontekstual tentang bangun ruang dan mempelajari kembali materi aljabar. Sebagian besar siswa mengalami kesulitan saat mencari nilai $t$ dari volume akhir yang sudah ditemukan sebelumnya. Siswa masih kesulitan dalam menyelesaikan perhitungan aljabar yang melibatkan variabel. Hal ini menunjukkan bahwa penguasaan aljabar siswa masih rendah. Alternatif lain juga dapat digunakan model pembelajaran yang sesuai dengan materi ini.

Selain itu, sebagian besar siswa juga tidak bisa menjawab sampai akhir dan adapun yang bisa menjawab sampai akhir namun hasilnya belum tepat. Hal ini menunjukkan bahwa siswa masih kesulitan jika melakukan perhitungan yang melibatkan pembagian bilangan yang besar. Latihan dan tes yang rutin terkait pembagian atau perkalian sangat perlu ditekankan karena dua operasi ini sangat penting dan banyak ditemukan dalam materi eksak. Hal ini ditekankan agar siswa tidak mengalami kesulitan kembali dalam mengerjakan soal-soal matematika.

\section{KESIMPULAN DAN SARAN}

Berdasarkan penelitian ini, dapat disimpulkan beberapa kesulitan yang dialami siswa. Kesulitan-kesulitan tersebut yaitu: (1) siswa mengalami kesulitan dalam memahami konsep dan definisi sehingga siswa tidak dapat menjelaskannya; (2) siswa mengalami kesulitan dalam menerapkan rumus dikarenakan siswa belum memahami konsep secara menyeluruh; dan (3) siswa mengalami kesulitan dalam perhitungan karena siswa masih belum menguasai operasi pada aljabar.

Berdasarkan kesimpulan tersebut dapat diberikan beberapa saran diantaranya yaitu: (1) sebaiknya siswa diberikan banyak latihan soal tentang aplikasi luas permukaan dan volume bangun ruang agar siswa dapat mengatasi kesulitan dalam memahami konsep dan definisi bangun ruang dan bisa menentukan kapan menggunakan rumus luas permukaan dan volume; (2) sebaiknya guru lebih memperhatikan tentang pembagian dan perkalian, karena dua operasi ini sangat penting dan banyak ditemukan dalam materi 
Syifa Khoirunnisa, Sulhan, Umi Kalsum, Dorkas Lali Timbu, Oktavianus Bulu Ngongo, Mika Ambarawati

Analisis Kesulitan Siswa dalam Menyelesaikan Soal Matematika Materi Luas Permukaan dan Volume Bangun Ruang Sisi Datar

eksak. Penelitian selanjutnya dapat dilakukan dengan berfokus pada peningkatan pemahaman siswa terkait materi luas dan volume dengan menerapkan model pembelajaran yang tepat dan aternatif yang disarankan dari hasil penelitian agar siswa dapat mengatasi kesulitan dalam pembelajaran matematika.

\section{DAFTAR RUJUKAN}

Agninditya, F., Sunandar, dan H. Purwati. (2014). Analisis Kesalahan dan Kesulitan Siswa dalam Menyelesaikan Soal Uraian Pokok Bahasan Trigonometri Kelas X.IIS di SMAN 1 Rembang. Prosiding Mathematics and Sciences Forum 2014. ISBN 978-602-0960-00-5. Hal: 795-798.

Chamundeswari, S. (2014). Conceptual Errors Encountered in Mathematical Operations in Algebra among Students at the Secondary Level. International Journal of Innovative Science. 1(8), 24-38.

Endah, Ayu S. dan Febrian. (2016). Dual Mode Error Analysis: Penyelesaian Permasalahan Luas Permukaan serta Volume Prisma dan Limas Siswa Kelas VIII SMP. Jurnal Gantang Pendidikan Matematika, 1(2), 25-37.

Hidayat, S. (2013). Pengembangan Kurikulum Baru. Bandung: PT Remaja Rosdakarya.

Humaerah, Sry Ratu. (2017). Analisis Kesalahan Siswa dalam Menyelesaikan Soal-soal pada Materi Geometri dengan Prosedur Newman Kelas VIII MTs Muhammadiyah Tanetea Kabupaten Jeneponto. Skripsi. Pendidikan Matematika UIN Alauddin Makassar.

Mahmud, Rauman. (2019). Analisis Kesulitan Belajar Siswa dalam Menyelesaikan Soal Luas Permukaan dan Volume Kubus. JUPITEK: Jurnal Pendidikan Matematika, 2(1),17-22.

Nurjanatin, Ina; Sugondo, Gatot; dan Manurung, Mayor M.H. (2017). Analisis Kesalahan Peserta Didik dalam Menyelesaikan Soal Cerita pada Materi Luas Permukaan Balok di Kelas F Semester II SMP Negeri 2 Jayapura. Jurnal Ilmiah Matematika dan Pembelajarannya, 2(1), 22-31.

Mutia. (2017). Analisis Kesulitan Siswa SMP dalam Memahami Konsep Kubus Balok dan Alternatif Pemecahannya. BETA: Jurnal Tadris Matematika, 10(1), 83-102.

Rizqiyyah, Nurul Fajriati. (2018). Analisis Kesulitan Siswa Dalam Menyelesaikan Soal Matematika Pada Kompetensi Dasar Menyelesaikan Masalah Yang Berkaitan Dengan Volume Kubus dan Balok Kelas V MI Nashrul Fajar Semarang Tahun Pelajaran 2017/2018. Skripsi. Semarang: UIN Walisongo. 
Syifa Khoirunnisa, Sulhan, Umi Kalsum, Dorkas Lali Timbu, Oktavianus Bulu Ngongo, Mika Ambarawati

Analisis Kesulitan Siswa dalam Menyelesaikan Soal Matematika Materi Luas Permukaan dan Volume Bangun Ruang Sisi Datar

Syahrir, Kusnadin, Nurhayati. (2013). Analisis Kesulitan Pemahaman Konsep dan Prinsip Materi Pokok Dimensi Tiga Siswa Kelas XI SMK Keperwatan Yahya Bima. Jurnal Prisma Sains, 1(1), 88-102.

Yulfiana. (2015). Analisis Kesulitan Siswa dalam Menyelesaikan Soal-soal Volume Bangun Ruang Sisi Lengkung pada Siswa Kelas IX SMP Muhammadiyah 9 Ngemplak Tahun Ajaran 2015/2016. Skripsi. Pendidikan Matematika Universitas Muhammadiyah Surakarta. 